\title{
IMMUNOHISTOCHEMISTRY QUANTIFICATION BY A DIGITAL COMPUTER-ASSISTED METHOD COMPARED TO SEMIQUANTITATIVE ANALYSIS
}

Leandro Luongo de Matos,* Elaine Stabenow,** Marcos Roberto Tavares,** Alberto Rosseti Ferraz,** Vera Luiza Capelozzi,*** Maria Aparecida da Silva Pinhal*

de Matos LL, Stabenow E, Tavares MR, Ferraz AR, Capelozzi VL, Pinhal MAS. Immunohistochemistry quantification by a digital computer-assisted method compared to semiquantitative analysis. Clinics. 2006;61(5):417-24.

PURPOSE: To compare immunostaining quantification obtained by a digital computer-assisted method with the well-established semiquantitative analysis.

METHODS: Cytoplasmic staining of galectin-3 was obtained by standard immunohistochemical reactions in 25 cases of welldifferentiated thyroid carcinoma. The expression index that associates the conventional area fraction of labeled cells with the immunostaining intensity score based on visual qualitative observation was used as the semiquantitative analysis. A digital computerassisted method is described based on the use of an image processing program (ImageLab $\left.{ }^{\circledast}\right)$. Three parameters were obtained: (1) percentage of labeled cells; (2) digital immunostaining intensity, and (3) digital expression index. The proposed method allows numerical analysis of the immunostaining intensity.

RESULTS: There was a strong correlation between the immunostaining intensity obtained by the two methods (Pearson correlation coefficient, $\mathrm{r}=0.71, P=0.0001$ ). The same was observed between expression indexes (Pearson correlation coefficient, $\mathrm{r}=0.66$, $P=0.0001)$.

CONCLUSION: Results obtained with our proposed digital computer-assisted method for immunoexpression analysis were concordant with the semiquantitative analysis. In addition, digital values can also resolve disagreement among different observers about the quality of staining intensity because the digital method does not classify the results into groups, but rather provides a numerical value for each individual case; thus, it increases the diagnostic and, more importantly, the prognostic sensitivity of the immunohistochemical analysis.

KEYWORDS: Digital computer-assisted image analysis. Immunohistochemical quantification. Galectin-3. Well-differentiated thyroid carcinoma.

\section{INTRODUCTION}

Immunohistochemistry is a well-established method in clinical practice that allows staining of cellular components

\footnotetext{
* Biochemistry Department, Molecular Biology Laboratory, Faculty o Medicine, ABC Foundation - São Paulo/SP, Brazil.

** Head and Neck Surgery Department, Hospital das Clínicas, São Paulo University Medical School - São Paulo/SP, Brazil.

*** Pathology Department, Immunohistochemistry Laboratory (Lim05), São Paulo University Medical School.

E-mail: Imatos@amcham.com.br

Received for publication on March 30, 2006.

Accepted for publication on June 19, 2006.
}

and extracellular matrix by specific antibodies. In surgical pathology, it is used as a diagnostic tool to differentiate benign and malignant tissues. As a prognostic tool, it is used to study the presence of molecules involved in cancer aggressiveness.

More than to identify the presence or absence of a biomarker, immunohistochemistry can be used to quantify its expression. Several histological quantification methods have been described. The most widely used technique for determining the area fraction of labeled cells is based on the point-counting method described by Gundersen ${ }^{2}$ in 1988. In 2001, Klein ${ }^{3}$ described the semiquantitative 
immunostaining score that associates the area fraction of labeled cells with a staining intensity score based on visual qualitative observation. This has now become a well-established method.

Computer-assisted analysis of digital images was used for the first time in 1980 to quantify immunostaining. ${ }^{4}$ Since then, several authors have applied this technology using different methods. ${ }^{5-16}$

Digital images can be translated into numerical values, and these values are able to describe staining intensity as a numeric variable, which is more precise than visual qualitative observation. Considering numerical data for staining intensity and percentage of labeled cells, a combined digital immunostaining index can be defined.

The purpose of this study was to compare immunostaining intensity quantification by a digital computer-assisted analysis with the semiquantitative method ${ }^{3}$ to verify the concordance of these techniques and identify advantages of one method over the other.

\section{METHODS}

Twenty-five consecutive cases of well-differentiated thyroid carcinoma classified according to World Health Organization criteria were studied. All patients were surgically treated at the Hospital das Clínicas of São Paulo University Medical School.

\section{IMMUNOHISTOCHEMICAL STAINING}

Representative tumor areas were chosen based on hematoxylin and eosin-stained sections. The corresponding archived paraffin-embedded specimens were sectioned into $3 \mu \mathrm{m}$ slices, and immunohistochemical staining was performed according to the standard avidin-biotin immunoperoxidase complex technique. Mouse monoclonal anti-human galectin-3 antibody (LabVision ${ }^{\circledR}$, California, USA) was diluted in a 1:40 proportion and used as the primary antibody.

The brownish-color was considered to be evidence of a positive expression of galectin-3 in the tumor cells. Histological slices of normal human tongue were used as controls. Unstained red blood cells and labeled foamy cells were considered, respectively, as negative and positive internal controls.

\section{QUANTIFICATION OF IMMUNOEXPRESSION}

Slides were analyzed using a TS100 Nikon Eclipse ${ }^{\circledR}$ light microscope to identify areas that best represented galectin-3 immunostaining (hot spots). For each case, the quantification of immunostaining was made by 2 different methods: semiquantitative and computer-assisted digital image analysis.

\section{Digital Computer-Assisted Method}

From each case, photomicrographs of 640x480 pixels were obtained from noncoincident consecutive fields, at a magnification of X400, with a 4300 Nikon Coolpix ${ }^{\circledR}$ digital camera, adjusted to these parameters. The obtained images were analyzed by the imaging processing and analysis system, ImageLab ${ }^{\circledR}$ (Softium Informática ${ }^{\circledR}$, São Paulo, Brazil), adjusted to the micrometric scale $(\mu \mathrm{m})$.

\section{Percentage of labeled cells (PLC)}

At least 1,000 tumor cells of epithelial origin, for each case, were counted by the ImageLab ${ }^{\circledR}$ while the observer classified them as positive or negative cells (Figure 1). Thus, the percentage of labeled cells (PLC) was determined, according to the following equation:

PLC $=\frac{\text { number of labeled cells }}{\text { total counted cells }} \times 100 \rightarrow[\%]$

\section{Digital Immunostaining Intensity $\left(\right.$ ITI $\left._{\text {dig }}\right)$}

ImageLab ${ }^{\circledR}$ was used to quantify the intensity of brownish-color immunostaining. For each case, the same photomicrographs used for determining the PLC were considered. Twelve randomized labeled cytoplasmic regions from different cells were indicated, with the same-sized square (tool of ImageLab ${ }^{\circledR}$ system). The average optical density (OD) of these areas was automatically calculated and represents the average of red, green, and blue color composition (RGB) per area of cytoplasm analyzed (Figure 2), expressed in optical units per micrometer squared $\left(\mathrm{ou} / \mu \mathrm{m}^{2}\right)$.

The same procedure was applied to obtain the background optical density (BOD) from an area without tissue or vascular space (Figure 3) for each photomicrograph. A single area was enough, since the background was constant in each photomicrograph.

The absolute white color that corresponds to the maximum optical density $\left(3207 \mathrm{ou} / \mu^{2}\right)$ is composed by the totality of red, green, and blue; and black is the absence of these colors. Therefore, the optical density values calculated by the program make up a decreasing scale in which the high values correspond to the colors that are visually clear.

The equation below was used to calculate the digital 
immunostaining intensity ( $\mathrm{ITI}_{\mathrm{dig}}$ ) for each case, whose values make up an increasing scale, equalized by the BOD, proportionally to the optical density of absolute white.

$\mathrm{ITI}_{\mathrm{dig}}=320.7-\frac{320.7 \times \Sigma \mathrm{OD}}{\Sigma \mathrm{BOD}} \rightarrow\left[\mathrm{ou} / \mu \mathrm{m}^{2}\right]$

\section{Digital expression index $\left(\mathrm{EI}_{\mathrm{dig}}\right)$}

The digital expression index $\left(\mathrm{EI}_{\mathrm{dig}}\right)$ was obtained by the multiplication of the PLC by digital immunostaining intensity $\left(\mathrm{ITI}_{\mathrm{dig}}\right.$ ) for each case, according to the following equation:

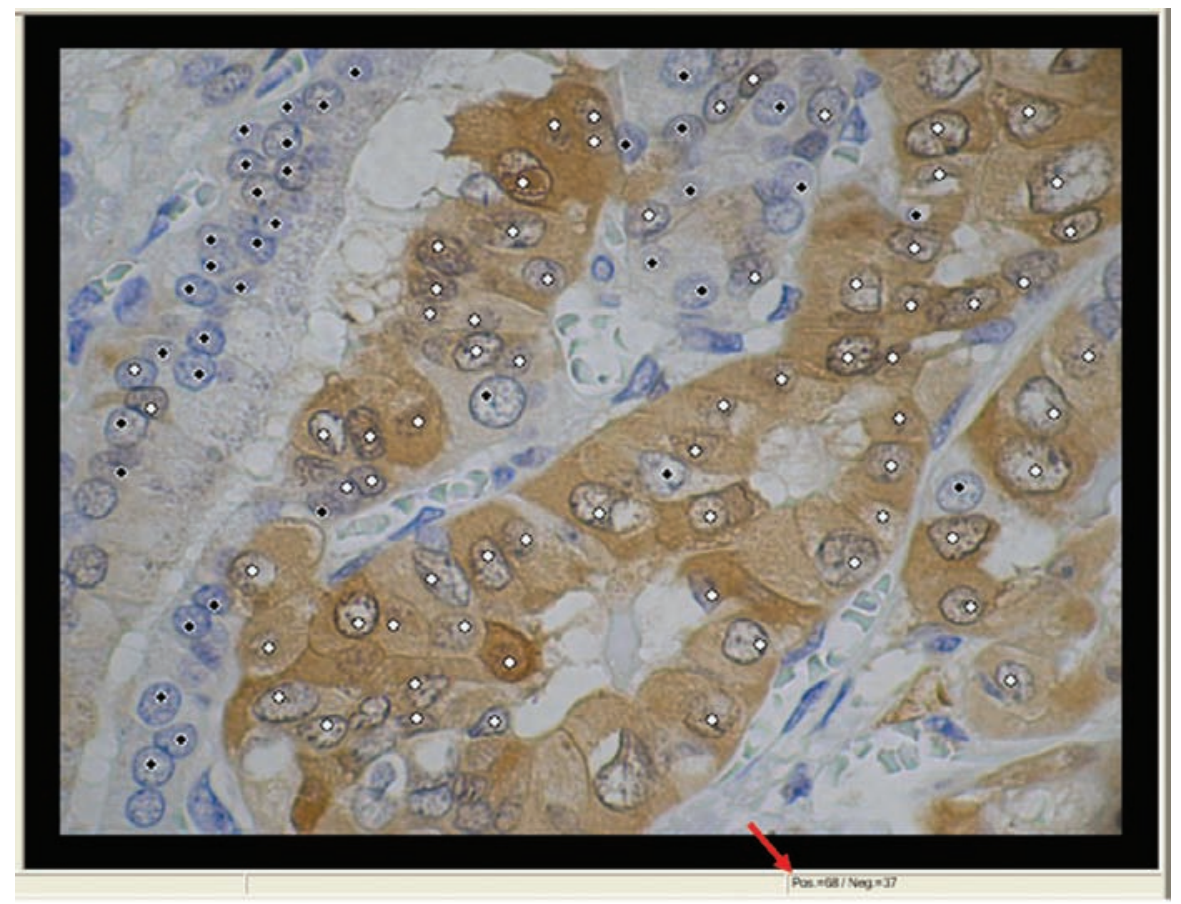

Figure 1 - Demonstration of ImageLab ${ }^{\circledR}$ software in the identification of positive labeled cells (white spots) and negative cells (black spots). The calculation of $\mathrm{PLC}_{\mathrm{DIG}}$ is indicated by the arrow.

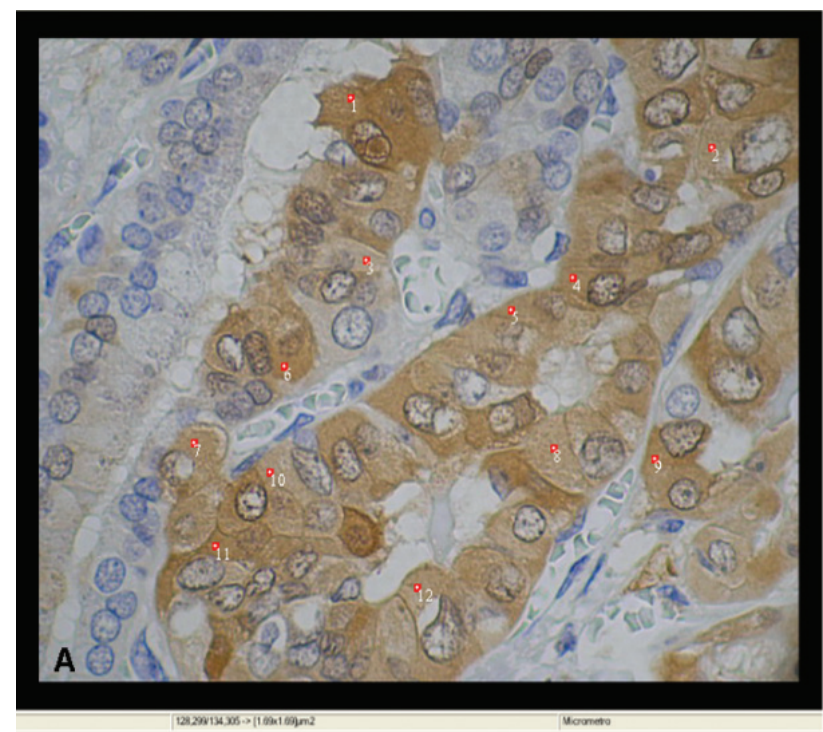

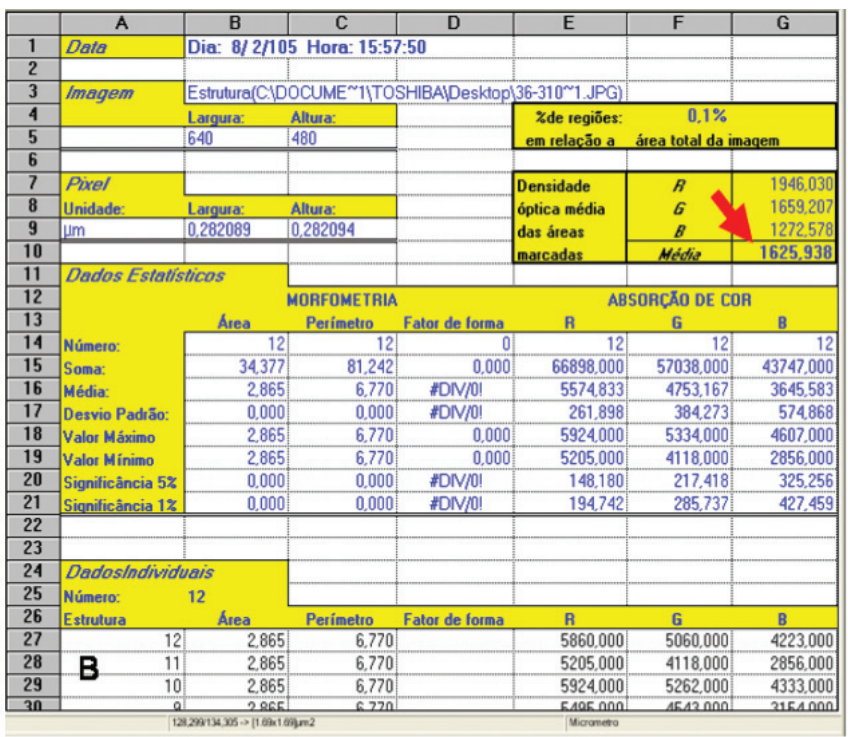

Figure 2 - ImageLab ${ }^{\circledast}$ software demonstration. (A) Manual determination of 12 cytoplasmic-labeled areas with peroxidase (red squares); (B) Tables showing the results, the arrow indicates the optic density of the total selected area. 


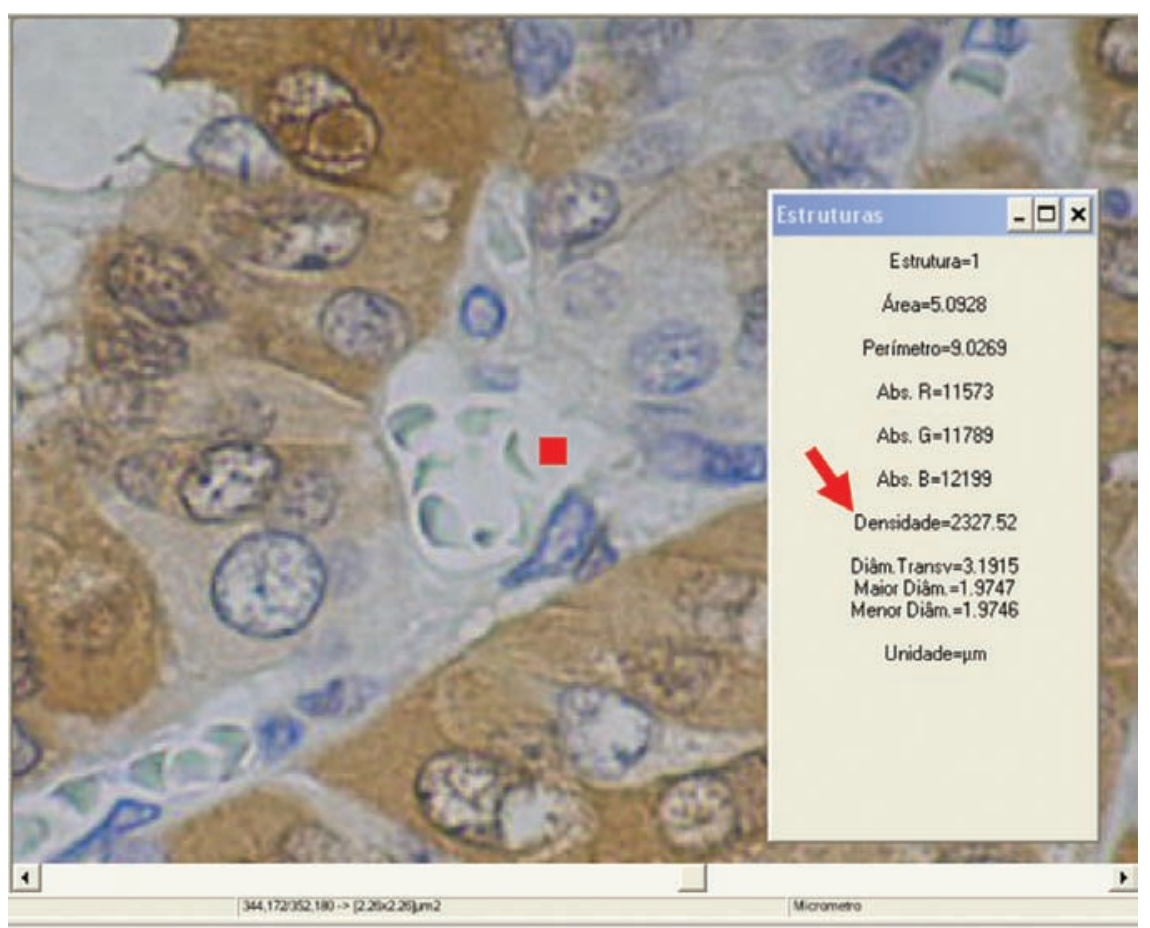

Figure 3 - ImageLab ${ }^{\circledast}$ software defining the area where there is no tissue reaction (red square) and the calculation of its optic density (arrow).

$\mathrm{EI}_{\mathrm{dig}}=\frac{\mathrm{PLC}}{100} \times \mathrm{ITI}_{\mathrm{dig}} \rightarrow\left[\mathrm{ou} / \mu \mathrm{m}^{2}\right]$

\section{Semiquantitative Analysis}

The semiquantitative analysis (as described by Klein) ${ }^{3}$ was obtained by calculation of the expression index $\left(\mathrm{EI}_{\mathrm{sq}}\right)$ that associates the area fraction of labeled cells (ALC) with the immunostaining intensity $\left(\mathrm{ITI}_{\mathrm{sq}}\right.$ ) obtained by visual qualitative observation categorized as described above.

Five noncoincident microscopic fields at X400 magnification were consecutively analyzed by the TS100Nikon Eclipse $^{\circledR}$ light microscope equipped with a 100-point grid. Labeled cells that coincided with grid points were counted, and the area fraction of labeled cells was determined according to the following equation:

$\mathrm{ALC}=\frac{\text { total of counted labeled cells }}{500} \times 100 \rightarrow[\%]$

The ALC values were categorized into 4 scores as follows: 0 , absence of labeled tumor cells; $1,0 \%$ to $10 \%$ of labeled tumor cells; 2 , from $11 \%$ to $50 \%$; and 3 , above $50 \%$ of labeled tumor cells. A score of 0 to 3 was attributed to the immunostaining intensity ( $\left.\operatorname{ITI}_{\mathrm{SQ}}\right)$ as follows: 0 , no staining; 1 , weak; 2, mild; 3, strong intensity. Finally, the expression index $\left(\mathrm{EI}_{\mathrm{SQ}}\right)$ was determined by multiplying the
ALC and the $\mathrm{ITI}_{\mathrm{SQ}}$ as follows: no staining, weak $(1,2$, or 3 points), mild (4 points) and strong (6, 7, or 9 points).

\section{RESULTS}

The ALC varied from $0 \%$ to $60.8 \%$ and PLC from $0 \%$ to $94 \%$. Only one case did not present cytoplasmic immunostaining.

The ITI $I_{\text {dig }}$ varied from 0 to $124.5 \mathrm{ou} / \mu \mathrm{m}^{2}$, with an average of $72.7 \pm 27.0 \mathrm{ou} / \mu \mathrm{m}^{2}$ The averages of the immunostaining intensity obtained by the digital method, according to the ITI $_{\mathrm{sq}}$ scores are shown in Table 1. There was a significant difference between the ITI $_{\text {dig }}$ average of the weak group and ITI $_{\mathrm{dig}}$ average of the strong group (ANOVA, $P=0.0001$; Bonferroni test, $P=0.003$ ), but no

Table 1 - Averages of galectin-3 ITI obtained by the digital computer-assisted method (ITI $\mathrm{DIG}_{\mathrm{DG}}$ ) according to the scores of staining defined by the semiquantitative analysis $\left(\mathrm{ITI}_{\mathrm{SQ}}\right)$.

\begin{tabular}{lcc}
\hline ITI $_{\text {SQ }}$ Scores & $\mathrm{n}$ & ITI $_{\text {DIG }}$ Average $*$ \\
\hline No staining & 1 & $0.0 \pm 0.0 \mathrm{ou} / \mu \mathrm{m}^{2}$ \\
Weak & 8 & $54.9 \pm 5.3 \mathrm{ou} / \mu \mathrm{m}^{2}$ \\
Mild & 7 & $72.9 \pm 17.3 \mathrm{ou} / \mu \mathrm{m}^{2}$ \\
Strong & 9 & $96.4 \pm 17.9 \mathrm{ou} / \mu \mathrm{m}^{2}$ \\
Total & 25 &
\end{tabular}

* Average \pm standard deviation (ANOVA. $P=0.0001$ ).

$\mathrm{n}$ : number of patients in each $\mathrm{ITI}_{\mathrm{SQ}}$ score. 
significant difference was found between them and ITI ${ }_{\text {dig }}$ average of the mild group. A significant correlation was observed between ITI sq $_{\text {and }}$ ITI $_{\text {dig }}$ (Pearson correlation coefficient, $\mathrm{r}=0.71, P=0.0001)$.

The $\mathrm{EI}_{\mathrm{dig}}$ varied from 0 to $94.2 \mathrm{ou} / \mu \mathrm{m}^{2}$, with an average of $47.6 \pm 26.9 \mathrm{ou} / \mu^{2}$. The averages of the immunostaining indexes of galectin- 3 obtained by the digital method, according to the immunostaining score defined by the semiquantitative method are represented in Table 2. There was significant difference between the $\mathrm{EI}_{\text {dig }}$ average of the weak group and $\mathrm{EI}_{\mathrm{dig}}$ average of the strong group (ANOVA, $\mathrm{P}=0.0001$; Bonferroni test, $P=0.007$ ), but no significant difference between them and $\mathrm{EI}_{\mathrm{dig}}$ average of the mild group. A significant correlation was observed between $\mathrm{EI}_{\mathrm{sq}}$ and $\mathrm{EI}_{\mathrm{dig}}$ (Pearson correlation coefficient, $\mathrm{r}=0.66, P$ $=0.0001)$.

Table 2 - Averages of galectin-3 EI obtained by the digital computer-assisted method $\left(\mathrm{EI}_{\mathrm{DIG}}\right)$ according to the scores of staining defined by the semiquantitative analysis $\left(\mathrm{EI}_{\mathrm{SQ}}\right)$

\begin{tabular}{lcc}
\hline EI $_{\text {SQ }}$ Scores & $n$ & EI $_{\text {DIG }}$ Average $*$ \\
\hline No staining & 1 & $0.0 \pm 0.0 \mathrm{ou} / \mu \mathrm{m}^{2}$ \\
Weak & 9 & $30.6 \pm 18.3 \mathrm{ou} / \mu \mathrm{m}^{2}$ \\
Mild & 5 & $54.3 \pm 27.1 \mathrm{ou} / \mu \mathrm{m}^{2}$ \\
Strong & 10 & $64.2 \pm 20.7 \mathrm{ou} / \mu \mathrm{m}^{2}$ \\
Total & 25 & \\
\hline
\end{tabular}

* Average \pm standard deviation (ANOVA. $P=0.0001$ ).

$\mathrm{n}$ : number of patients in each $\mathrm{EI}_{\mathrm{SQ}}$ score.

\section{DISCUSSION}

This paper describes a digital computer-assisted quantification method of immunostaining for biological markers by the immunohistochemical technique, using cytoplasmic staining of galectin-3 in well-differentiated thyroid carcinomas. It is important to note that this method has been used with other biological markers by immunohistochemistry in many types of tumors (for example, heparanase, caspase-3, bcl-2, bax, CEA, and prolactin-3 in lung, ovarian, breast, rectal cancers, and melanoma), showing similar statistically significant results.

The semiquantitative method of immunostaining intensity $\left(\mathrm{ITI}_{\mathrm{SQ}}\right)$ was used by Klein et $\mathrm{al}^{3}$ in a study of immunohistochemical expression of the vascular endothelial growth factor in thyroid papillary carcinoma. Through visual observation and the use of a scoring system, they classified immunostaining intensity as absent, weak, mild, or strong. Generally, digital image processing aims to improve the quantification of immunostaining ${ }^{17}$ and does not classify results into groups.

Two independent observers can describe the immunostaining intensity of a determined area in different ways. Weaker- or stronger-stained areas do not require deeper discussions because independent observers usually agree on these categories. However, moderate upper or lower borderline-staining intensity can cause problems. In these cases, techniques that establish a numerical value for the staining intensity offer a uniform way to quantify the intensity in a defined area. ${ }^{17}$ Software capture of immunohistochemical images can be used for this purpose, as in the method that is being proposed here.

The results of this study show that for extreme staining intensities, there was a high concordance between the semiquantitative and the digital methods. In contrast, tumors with mild intensity scores produced divergent results between semiquantitative and digital immunostaining intensity analysis. This suggests that there is disagreement between observers about the quality of intermediary intensities that could be resolved by the proposed digital quantification.

Tomatis et $\mathrm{al}^{18}$ reported that an image analysis system was more precise than visual observation for separating melanomas from benign nevus, mainly in the intensity of hyperpigmentation and variety of colors of the lesion, suggesting greater accuracy with the digital quantification method compared to conventional visualization. Ruifrok ${ }^{19}$ used digital image analysis to quantify the immunostaining of the growth factors EGF and TNF for the diaminobenzidine chromogen in fasting mice, separating, by manual subtraction of the RGB, the hematoxylin marking. Other authors ${ }^{20-22}$ have used the automatic subtraction of RGB using the "magic wand tool," available in the Photoshop ${ }^{\circledR}$ software, to determine the immunostaining intensity and in an attempt to quantify the concentration of antibodies used in the immunohistochemistry. This automated form has the inconvenience of introducing small errors into the final reading of the immunostaining intensity in cases where the limits among the colors to be subtracted are imprecise. It is also not possible to separate immunostaining of areas outside the cell compartment to be studied. ${ }^{17}$ Moreover, tumor regions not exactly expressing the ITI expression chosen for the analysis are not considered in the calculation and, therefore, are not represented. ${ }^{17}$ In our proposed method, the optic density of immunoexpression is determined without the subtraction of RGB for the determination of only the cytoplasmic area of the labeled cells in all the photomicrographs studied, thus representing the immunostaining intensity diversity case by case, without the possibility of going askew and considering structures that should not be analyzed and of leaving out regions more or less expressed.

When the digitalization of an image is done, the color 
tones do not occupy all the scales available; that is a particular and intrinsic feature of each obtained photomicrograph, making comparison between two photomicrographs impossible. To get around this situation, the scale of colors can be modified artificially so that they occupy the same and greatest interval possible. This procedure has been named equalization. ${ }^{17}$ Many investigators do not recognize the importance of this fact ${ }^{18-23}$ and so do not equalize the images obtained, possibly causing errors in obtaining the ITI values. One form of equalization is the use of digital cameras of the highest resolution with the best light filters. ${ }^{24}$ The images thus obtained have exactly the same color spectrum, but this equipment increases the cost of the system, limiting its utility. The method proposed in this study uses a simple algorithm for the equalization of images that makes the measurement of the ITI proportional to the background optic density (BOD), in relation to the optic density of absolute white, for each photomicrograph analyzed. This solves the intrinsic problems of the immunohistochemical method itself as well as the problem of the electronic noise that can result in a color spectrum that is different among the digital images; it also enables a comparison of the immunostaining among the different cases analyzed.

In contrast to the methods proposed by other investi- gators who have sought to measure the concentration of the chromogen by obtaining its intensity ${ }^{20,22}$ and expression index, ${ }^{23}$ the method described in this study aims to enable a comparison among the cases without the application of intensity scores. ${ }^{3}$

By comparing immunostaining quantification obtained by a digital computer-assisted method with a well-established semiquantitative analysis, we conclude that results of both methods are concordant. However, digital measurement could resolve disagreement between two observers about the quality of staining intensity because the digital method does not classify the results into groups, but rather provides a numerical value for each individual case and, thus, increases the diagnostic and, above all, prognostic sensitivity of the immunohistochemical analysis.

\section{ACKNOWLEDGEMENTS}

We express our gratitude to Sandra de Moraes Fernezlian, Esmeralda Miristene Eher, Angela Batista dos Santos (Immunohistochemical Laboratory), technicians of the Pathology Department of the University of São Paulo Medical School (Lim05), for the vital role they played and dedicated work in the immunohistochemical reactions. This study was supported by NEPAS, FAPESP and CAPES.

\section{RESUMO}

de Matos LL, Stabenow E, Tavares MR, Ferraz AR, Capelozzi VL, Pinhal MAS. Método digital assistido por computador de quantificação imunohistoquímica comparado à análise semiquantitativa. Clinics. 2006;61(5):417-24.

OBJETIVO: Comparar a quantificação da imunomarcação através de um método digital assistido por computador à bem estabelecida análise semiquantitativa.

MÉTODO: A marcação citoplasmática de galectina-3 foi obtida por reações imunohistoquímicas em 25 casos de carcinoma bem-diferenciado da glândula tireóide. Determinouse o índice de expressão da análise semiquantitativa que associa a convencional fração de área de células marcadas com os escores de intensidade da imunoexpressão, com base na observação visual qualitativa. $\mathrm{O}$ método digital assistido por computador foi desenvolvido com o uso de um programa de análise de imagem (ImageLab ${ }^{\circledR}$ ). Três parâmetros foram obtidos: (1) porcentagem de células marcadas; (2) intensidade de imunoexpressão digital e (3) índice de expressão digital. $\mathrm{O}$ método proposto resulta na análise numérica da intensidade de imunoexpressão.

RESULTADOS: Houve importante correlação entre as intensidades de imunoexpressão obtidas pelos dois métodos (coeficiente de correlação de Pearson, r=0,71, p=0,0001). 
O mesmo foi observado entre os índices de expressão (coeficiente de correlação de Pearson, $r=0,66, p=0,0001$ ).

DISCUSSÃO: Os resultados de intensidade de imunoexpressão obtidos com o emprego do método digital assistido por computador foram concordantes com os escores da análise semiquantitativa. Entretanto, os resultados alcançados com o emprego do método digital podem resolver a discordância entre diferentes observadores com relação a esta intensidade de imunomarcação. Além disso, o método proposto não categoriza os resultados em grupos, o que torna a análise imunohistoquímica numericamente mensurável individualmente, aumentando seu poder diagnóstico e, sobretudo, prognóstico.

UNITERMOS: Análise digital de imagens. Quantificação imunohistoquímica. Morfometria. Galectina-3. Carcinoma bem-diferenciado da tireóide.

\section{REFERENCES}

1. Alves VAF, Bacchi CE, Vassallo J. Manual de imuno-histoquímica. São Paulo: Sociedade Brasileira de Patologia; 1999.

2. Gundersen HJ, Bendtsen TF, Korbo L, Marcussen N, Moller A, Nielsen $\mathrm{K}$, et al. Some new, simple and efficient stereological methods and their use in pathological research and diagnosis. Apmis. 1988;96:379-94.

3. Klein M, Vignaud JM, Hennequin V, Toussaint B, Bresler L, Plénat F, et al. Increased expression of the vascular endothelial growth factor is a pejorative prognosis marker in papillary thyroid carcinoma. J Clin Endocrinol Metab. 2001;86:656-8.

4. Schuh D, Steidl R, Voss K. The differential diagnosis of follicular adenomas and carcinomas in fine needle biopsies of the thyroid gland by means of automatic image analysis. Zentralbl Allg Pathol. $1980 ; 124: 557-60$

5. Zhu QY. Analysis of blood vessel invasion by cells of thyroid follicular carcinoma using image processing combined with immunohistochemistry. Zhonghua Yi Xue Za Zhi. 1989;69:573-5.

6. Holschbach A, Kriete A, Schaffer R. Differential diagnosis of papillary carcinomas of the thyroid, using image analysis and three dimensional reconstruction from serial sections. Verh Dtsch Ges Pathol. 1990;74:2704.

7. Jensen MH, Davis RK, Derrick L. Thyroid cancer: a computer-assisted review of 5287 cases. Otolaryngol Head Neck Surg. 1990;102:51-65.
8. Salmon I, Kiss R, Franc B, Gasperin P, Heimann R, Pasteels JL, et al. A. Comparison of morphonuclear features in normal, benign and neoplastic thyroid tissue by digital cell image analysis. Anal Quant Cytol Histol. 1992; 14:47-54.

9. Tseleni S, Kavantzas N, Yova D, Alexandratou E, Karydakis V, Gogas $\mathrm{J}$, et al. Findings of computerised nuclear morphometry of papillary thyroid carcinoma in correlation with known prognostic factors. J Exp Clin Cancer Res. 1997;16:401-6.

10. Gordower L, Decaestecker C, Kacem Y, Lemmers A, Gusman J, Burchert M, et al. Galectin-3 and galectin-3-binding site expression in human adult astrocytic tumours and related angiogenesis. Neuropathol Appl Neurobiol. 1999;25:319-30.

11. Gupta N, Sarkar C, Singh R, Karak AK. Evaluation of diagnostic efficiency of computerized image analysis based quantitative nuclear parameters in papillary and follicular thyroid tumors using paraffinembedded tissue sections. Pathol Oncol Res. 2001;7:46-55.

12. Kavantzas N, Tseleni-Balafouta S, Davaris P. Computerized nuclear morphometry and quantitation of angiogenesis in thyroid neoplasms. J Exp Clin Cancer Res. 2002;21:247-54.

13. Rosal MA, Goncalves WJ, Alves MT, Baracat EC, de Lima GR. Histopathological and immunohistochemical analysis (proliferating cell nuclear antigen) of patients with invasive cervical carcinoma before and after radiotherapy and surgery. Rev Assoc Med Bras. 2002;48:32-5. 
14. Silva Junior AN, Pinheiro AL, Oliveira MG, Weismann R, Ramalho LM, Nicolau RA. Computerized morphometric assessment of the effect of low-level laser therapy on bone repair: an experimental animal study. J Clin Laser Med Surg. 2002;20:83-7.

15. Rald DP, Lage-Marques JL. In vitro evaluation of the effects of the interaction between irrigating solutions, intracanal medication and Er:YAG laser in dentin permeability of the endodontic system. Pesqui Odontol Bras. 2003;17:278-85.

16. Borra RC, Andrade PM, Silva ID, Morgun A, Weckx LL, Smirnova AS, et al. The Th1/Th2 immune-type response of the recurrent aphthous ulceration analyzed by cDNA microarray. J Oral Pathol Med. 2004;33:140-6.

17. Novelli MD, Barreto E, Matos D, Saad SS, Borra RC. Computer-assisted image processing for quantifying histopathologic variables in the healing of colonic anastomosis in dogs. Rev Ass Med Brasil. 1999;43:277-82.

18. Tomatis S, Bono A, Bartoli C, Tragni GBF, Marchesini R Image analysis in the RGB and HS colour planes for a computer-assisted diagnosis of cutaneous pigment lesions. Tumori. 1998;84:29-32.

19. Ruifrok AC. Quantification of immunohistochemical staining by color translation and automated thresholding. Anal Quant Cytol Histol. 1997;19:107-13.
20. Lehr H, Mankoff DA, Corwin D, Santeusanio G, Gown AM. Application of Photoshop-based image analysis to quantification of hormone receptor expression in breast cancer. J Histochem Cytochem. 1997;46:1559-65.

21. Lehr H, van der Loos CM, Teeling P, Gown AM. Complete chromogen separation and analysis in double immunohistochemical stains using Photoshop-based image analysis. J Histochem Cytochem. 1999;47:11925.

22. Matkowskyj K, Cox R, Jensen RT, Benya RV. Quantitative immunohistochemistry by measuring cumulative signal strength accurately measures receptor numbers. J Histochem Cytochem. 2003;51:205-14.

23. Kohlberger PD, Kieback DG, Breitenecker F, Loesch A, Gitsh G, Kainz $\mathrm{C}$, et al. Epithelial and stromal estrogen and progesterone receptor expression in endometrial cancer: true color computer-assisted image analysis versus subjective scoring. Gynecol Oncol. 1997;64:404-10.

24. Ornberg RL, Woerner BM, Edwards DA. Analysis of stained objects in histological sections by spectral imaging and differential absorption. J Histochem Cytochem. 1999;47:1307-13. 